\title{
消化管スパイスセンサーとその機能：辛味は胃腸でも味わう
}

\author{
堀 江 俊 治, ${ }^{*}, a$ 田嶋 公 ${ }^{a}{ }^{a}$ 松本健次郎 $b$
}

\section{Gastrointestinal Spice Sensors and Their Functions}

\author{
Syunji Horie, ${ }^{*, a}$ Kimihito Tashima, ${ }^{a}$ and Kenjiro Matsumoto ${ }^{b}$ \\ ${ }^{a}$ Faculty of Pharmaceutical Sciences, Josai International University; 1 Gumyo, Togane, Chiba 283-8555, Japan: \\ and ${ }^{b}$ Department of Pharmacology and Experimental Therapeutics, Kyoto Pharmaceutical University; \\ 5 Nakauchi-cho, Misasagi, Yamashina-ku, Kyoto 607-8414, Japan.
}

(Received March 3, 2017)

\begin{abstract}
Capsaicin is a constituent of chili pepper, and induces the burning sensation on the tongue. The site of action for capsaicin has been discovered as transient receptor potential vanilloid receptor subtype 1 (TRPV1) that resides on the membranes of pain- and heat-sensing primary afferent nerves. The immunohistochemical study on the stomach revealed that nerve fibers expressing TRPV1 exist along gastric glands in the mucosa, around blood vessels in the submucosa, in the myenteric plexus, and in the smooth muscle layers. High numbers of TRPV1-immunoreactive axons were observed in the rectum and distal colon. Therefore, capsaicin stimulates TRPV1 not only on the tongue but also in the gut. In this review, the mechanism of gastrointestinal mucosal defense enhanced by capsaicin was summarized. TRPV1 plays a protective role in gastrointestinal mucosal defensive mechanism. Hypersensitivity of afferent fibers occurs during gastrointestinal inflammation. Abnormalities of primary afferent nerve fibers are strongly associated with the visceral hypersensitive state in inflammatory bowel disease (IBD). The alteration of TRPV1 channels in mucosa contributes to the visceral hypersensitivity in colitis model mice. TRPV1-expressing neurons in the gut are thought to be extrinsic sensory afferent neurons that operate to maintain gastrointestinal functions under physiological and inflammatory states.
\end{abstract}

Key words_ capsaicin; visceral hyperesthesia; sensory nerve; transient receptor potential vanilloid receptor subtype 1; pharmacology

\section{1. はじめに 辛味はひりひりする痛み}

トウガラシの辛味の本体はトウガラシ果実中に含 有されるカプサイシン及びその類縁化合物である. トウガラシを摂取した場合に引き起こされる生理作 用の多くは，このカプサイシン類（カプサイシノイ ド）によるものと考えられる. その化学構造は脂肪 酸とバニリルアミンがアミド結合した脂溶性化合物 であるため, 細胞膜を通過し易く組織への浸透性は 高い. カプサイシンの辛味は, 味覚を感じる舌の味 蕾を通り抜けて，その深部にあるカプサイシン感受 性知覚神経で感受されている。したがって，辛味は 味蕾で感受しているのではないので，味覚ではな

a城西国際大学薬学部薬理学研究室（干283-8555 千葉 県東金市求名 1$), b$ 京都薬科大学薬物治療学分野 (干607-8414 京都市山科区御陵中内町 5)

*e-mail: shorie@jiu.ac.jp

本総説は, 日本薬学会第 136 年会シンポジウムS36で

発表した内容を中心に記述したものである.
い. カプサイシンの一次知覚神経に対する作用は選 択性が高く，他の神経や他の作用点にはあまり作用 しない. カプサイシン感受性知覚神経とは, カプサ イシンにより選択的に活性化される求心性一次知覚 神経で，主に無髄の C 線維である。卜ウガラシを 食べてから「辛い」と感じるまでにはタイムラグが ある。これはカプサイシンが組織深部に徐々に浸潤 する速さに由来している。

熱い温度の知覚についても, 熱刺激がカプサイシ ンセンサーにより活動電位に変換され, 知覚神経を 介して脳に伝えられる。高温は生命を脅かすので, その温度感覚は危険を避けるために痛みが付加され た強いシグナルになっている. すなわち, 約 $43^{\circ} \mathrm{C}$ 以上の温度は温度感覚に加えて痛みをもたらすが, これは高温の温度感覚にプラスして痛みを加えるこ とによって脳の対応をすばやくするためである。卜 ウガラシを食べると口の中でやけつくような熱さと ひりひりした痛みを感じるのは，カプサイシンに 
よってカプサイシンセンサーが活性化されるため, 侵害性熱刺激と同じ情報が知覚神経を介して脳に伝 えられるからである。したがって，辛味はひりひり する痛みであると言える。

\section{2. トウガラシの作用点 Transient receptor} potential vanilloid receptor subtype 1 (TRPV1)

TRPV1 は求心性一次知覚神経に発現し, 生体で は熱や酸による痛みの神経伝達に重要な役割を担っ ている．この TRPV1 発現知覚神経は口腔内だけで はなく，消化管全域に発現しており，その機能が明 らかにされてきている。

カプサイシンのモレキュラーターゲットは, 1997 年にカプサイシン感受性一次知覚神経細胞に存在す るバニロイド受容体（カプサイシン受容体）として 発見された。バニロイド受容体はラットの場合 838 個のアミノ酸からなるタンパク質で，6回膜貫通型 のカチオンチャネル構成型受容体であり, transient receptor potential (TRP) スーパーファミリーに分 類されている．発見当初は vanilloid receptor subtype 1（VR1）と名づけられたが，TRP スーパー ファミリーを構成することが判明し，現在は TRPV1のよび方が定着した. ${ }^{1)}$

カプサイシンが TRPV1 に結合すると，構成され ている非選択的力チオンチャネルが開孔し，細胞外 から細胞内にカルシウムやナトリウムイオンが流入 し，これが引き金となって一次知覚神経細胞に活動 電位が発生する。この活動電位が軸索を伝導すると 神経終末から神経ペプチドが放出され，情報が伝達 されることになる。TRPV1 は $43^{\circ} \mathrm{C}$ を超える侵害性 の熱刺激によっても活性化されるため，熱刺激受容 体とも呼ばれている. ${ }^{2)}$

TRPV1 が活性化される $43^{\circ} \mathrm{C}$ という温度は生体に 痛みを引き起こす温度䦨値でもあることから， TRPV1 は単なる高温を感受するだけでなく，侵害 性熱刺激を感受する役割も有することが明らかと なっている，TRPV1が動物体内で実際に熱感受性 受容体として機能していることは，TRPV1 遺伝子 を欠損したマウスにおいて熱刺激の反応性が悪いと いう研究結果によって確かめられている. ${ }^{3)}$

\section{3. 上部消化管における TRPV1 発現知覚神経の} 分布と役割

消化管の知覚神経は大きく分けて，細胞体を筋間 神経叢あるいは粘膜下神経叢に持つ内在性知覚神経

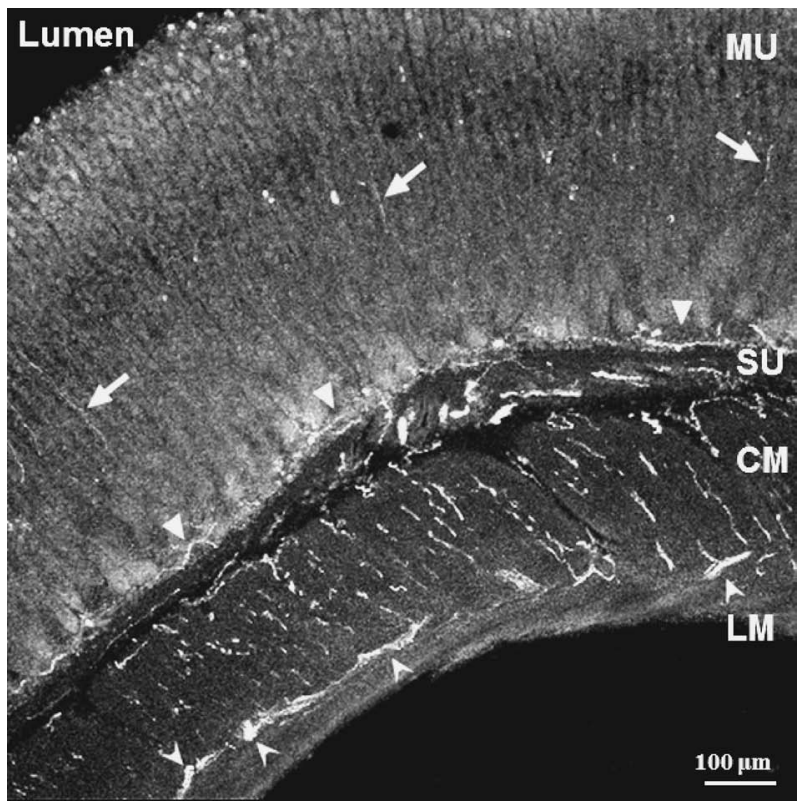

Fig. 1. Distribution of TRPV1-immunoreactivity in the Corpus of the Stomach

A low magnification image showing that TRPV1-immunoractivity is present in all layers of the stomach wall. Arrows, arrowheads and concave arrowheads indicate TRPV1-immunoreactivity in mucosa, lamina propria and myenteric plexus, respectively. Scale bar is $100 \mu \mathrm{m}$. MU: mucosa; SU: submucosa; CM: circular muscle; LM: longitudinal muscle.

と，細胞体を脊髄後根神経節あるいは節上神経節に 持つ外来性知覚神経に分類される。この中で，平滑 筋層，筋間神経丵，粘膜下層や粘膜層に分枝を持つ ような外来性知覚神経がカプサイシンに感受性であ ることは以前より知られていた。 カプサイシン感受 性神経は TRPV1 発現知覚神経であり，管腔や消化 管壁の化学的・物理的变化に応答し，軸索-軸索反 射によって消化活動，粘膜血流，運動性，分泌活動 に影響を与えていると考えられる.

カプサイシン感受性知覚神経は，胃に豊富に存在 し，外部侵害刺激を感知し粘膜防御機構を賦活させ ると考えられている．免疫組織化学的手法による検 討によって，TRPV1 様免疫反応が胃体部切片にお いて神経線維状に観察された（Fig. 1). 4) 神経マー カーPGP9.5 との共局在から，TRPV1 が神経に発 現することを確認し，その発現は胃粘膜層，平滑筋 層, 神経叢などすべての層で認められた。しかし， TRPV1 様免疫反応が観察されたのは神経線維上の みで神経細胞体上には観察されなかつた。したがつ $\tau, T R P V 1$ は外来性知覚神経（多くは脊髄神経由 来であり，迷走神経に由来するものは一部）に発現 していると示唆した. ${ }^{4)}$ 


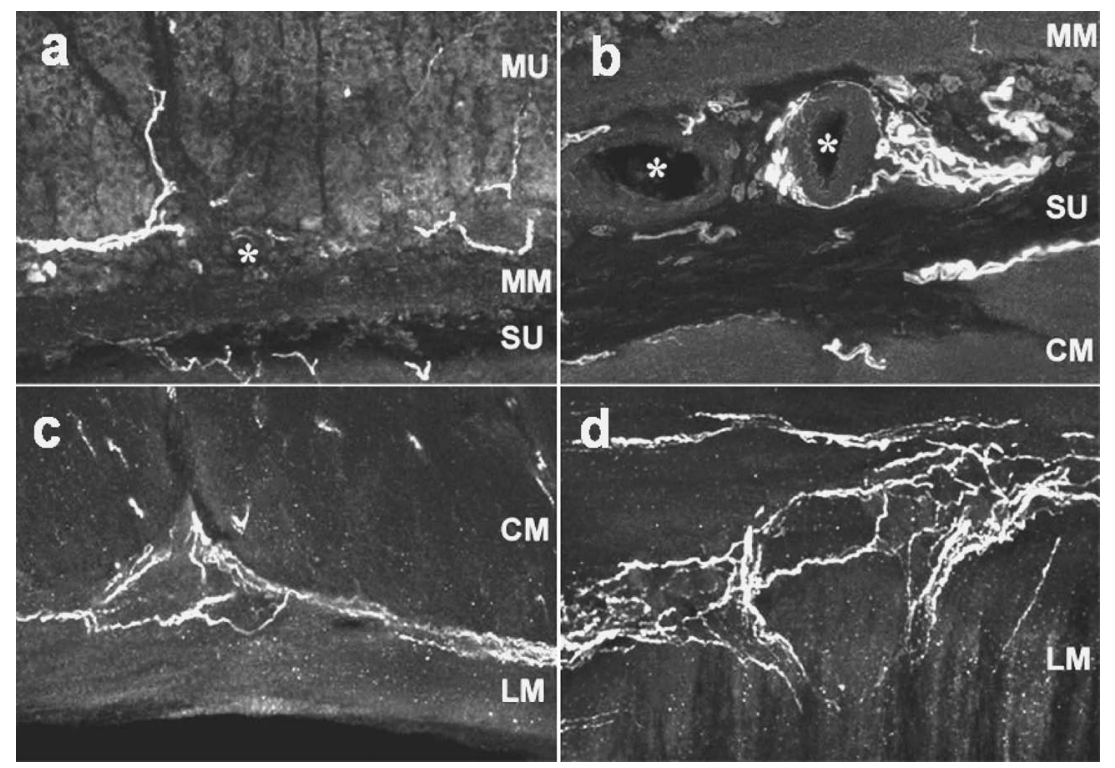

Fig. 2. Localization of TRPV1-immunoreactivity in the Corpus of the Stomach in Mucosa (a), Submucosa (b) and Smooth Muscle Layer (c, d)

(a) TRPV1-immunoreactive fibers arise from lamina propria and enter the mucosa. (b) Numerous TRPV1-immunoreactive fibers are found around blood vessels (asterisks) in the submucosal layer. (c) A large number of nerve fibers are seen in circular smooth muscle layer and in the myenteric nerve plexus. (d) Bundles of TRPV1 nerve fibers are visible running between myenteric plexus and the outer connective tissue of the serosa. MU: mucosa; SU: submucosa; CM: circular muscle; LM: longitudinal muscle; LP: lamina propria; MM: muscularis mucosae.

胃粘膜層では胃腺に沿うようにまっすぐに TRPV1 神経線維が走っており，胃粘膜の表層にあ る被蓋上皮細胞の近くまで到達していた。これらの 観察より，TRPV1 神経は胃管腔内の胃酸や辛味性 化学物質を受容するアンテナ的な役割を担っている と考えられる.

TRPV1 発現神経線維は胃粘膜層ばかりでなく, 粘膜下層の血管周囲と筋間神経叢に豊富に存在して いることも観察した（Fig. 2)。これは，カプサイ シン感受性の TRPV1 発現神経線維が胃粘膜血流と 平滑筋運動を調節しているというこれまでの生理学 的知見をサポートする結果であると考えている.

ラット摘出胃標本の部位における TRPV1 発現神経 線維の分布量を比較すると，前胃部，胃体部と比較 して胃幽門洞部に多く分布していた。胃幽門洞はヒ 卜胃潰瘍の好発部位であることから，カプサイシン 感受性知覚神経は胃潰瘍と密接に関連していること が考えられる，上述したように，TRPV1を遮断し たり，カプサイシン神経を除神経処置したりすると， ラット胃幽門洞潰瘍がさらに悪化するが，これは胃 幽門洞部に TRPV1 発現神経線維が多いためである と考えられる.

\section{4. カプサイシンの胃粘膜保護作用}

チリペッパーが多量に入っている料理（例えば夕
イ料理）を食べると舌が麻痺してしまい，その後は 料理の味がわからなくなってしまうことを経験す る.この麻痺はカプサイシンの長時間暴露（あるい は繰り返し暴露）による知覚神経の機能的麻痺（脱 感作反応）によると考えられる.

興味深いことに，健常人ボランティアにおいてチ リペッパーを前服用しておくと，アスピリンによる 胃・十二指腸潰瘍の発生が有意に抑制されることも 報告されている. ${ }^{5)} こ れ ら の$ 報告より, トウガラシ は胃に対して保護的に働くということが明らかと なってきた。実験動物ラットを用いた基礎研究から も，トウガラシ辛味成分カプサイシンが顕著に胃損 傷・胃潰瘍発生を抑制することがいくつか報告され

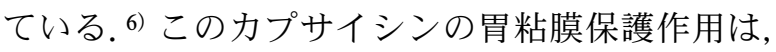

TRPV1 遮断薬の前処置やカプサイシン感受性知覚 神経の除神経処置により消失することから，カプサ イシンは知覚神経上の TRPV1 を活性化することに より胃粘膜保護作用を示すことがわかつた. $\left.{ }^{6}\right)$

TRPV1 は痛夕を惹起する酸（プロトン）によっ ても活性化される，例えば，胃が荒れたときは，胃 酸が胃粘液層を通過し, 胃粘膜層に浸潤してくる.

TRPV1 がプロトンを受け止め，この非常事態を感 知すると，すみやかに脳に非常事態を伝達すると同 時に，軸索一軸索反射により TRPV1 発現知覚神経 
終末から CGRP やタキキニン，さらに一酸化窒素 （NO）が遊離される。また，別の胃粘膜防御物質 であるプロスタグランジンや NO などの産生が増 大して，それらが協調しあって，胃粘膜血流増加や 胃粘液分泌充進，胃酸分泌抑制など，様々な胃粘膜 防御機構を増強することによって，胃粘膜を保護す ると考えられている.7)

実験動物を用いた検討において，カプサイシン低 用量では胃粘膜防御能を充進させるが，非常に多量 に投与するとカプサイシン感受性神経が退行変性 し，胃潰瘍はかえって悪化することが報告されてい

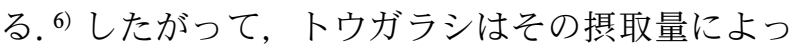
て，胃に対して相反する薬理作用を示すと考えられ る。私たちも，独自に開発したラットの新規胃幽門 洞潰瘍モデルを用い，胃潰瘍に対するカプサイシン の薬理作用を検討した。 その結果，少量のカプサイ シンは胃幽門洞潰瘍形成を抑制し，潰瘍治癒速度を

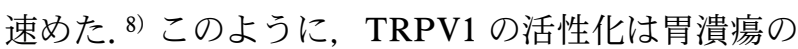
治癒過程にも大きな影響を有することがわかってき ている.

TRPV1 発現知覚神経を介する胃粘膜血流増加作 用は，胃粘膜保護だけでなく，胃損傷の修復・治癒 過程においても重要であり，急性・慢性胃潰瘍の治 癒にとって大きな意義を持つこともわかった。 トウ ガラシ先進国であるハンガリーでは，アスピリンや インドメタシンといった非ステロイド性抗炎症薬に トウガラシエキスを添加した製剤を開発しつつあ る. トウガラシエキスの添加によって非ステロイド 性抗炎症薬の副作用である消化性潰瘍の発生を抑制 するというコンセプトの製剤開発である.

\section{5. トウガラシによる胃潰瘍の増悪}

古くから，香辛料の摂取は胃を保護するという事 実は知られている。 また，トウガラシ，ショウガは 薬理学の教科書にも「辛味健胃薬」として登場して くる. 生薬学の教科書では蕃椒（ばんしょう）と称 され，健胃作用を有すると記載されている。これま での研究成果からも, 低用量のカプサイシンはむし ろ胃粘膜保護的に作用し，胃損傷の治癒を促進する と考えられる.

薬剤師は胃潰瘍の人，胃が荒れている人は香辛料 を控えるように指導する，不思議なことに，カプサ イシンは胃保護作用があることは上述の通りで明白 である。この矛盾はどこから来るのであろうか？
香辛料も適度適量であれば胃の環境にとってはよい ストレッサーであろうと考える。しかし，適量を超 すと取り返しがつかないことになる。炎症が発生し ている胃では，TRPV1の発現が増大し，さらにカ プサイシン感受性も克進しているため, 薬理用量の 摂取でも過剩量の摂取と同じになってしまうものと 思われる。したがって，トウガラシの摂取を控える に越したことがない。

動物実験デー夕をヒトに外挿するのは乱暴ではあ るが，健常人の胃では結構な量を摂っても胃損傷が 引き起こされることはないと思われる。ヒトにおい てどの程度までが健胃作用の用量（薬理用量）で, どの量からが有害作用の用量（神経毒性用量）かと いうことに関しても不明であるので，更なる研究が 必要である。韓国では，キムチなどで子供の頃から かなりのトウガラシを摂取しているが，韓国の人々 は胃潰瘍に悩むケースが多いという。実験動物を用 いた検討においても，カプサイシンは低用量では胃 粘膜防御能を六進させるが, 多量に投与するとカプ サイシン感受性神経が退行変性し, 胃粘膜防御機構 が脆弱して，胃潰瘍はかえって悪化することはよく 知られている.

私たちも，胃幽門洞潰瘍モデルラットを用い，胃 潰瘍に対するカプサイシンの薬理作用を検討した. その結果，少量のカプサイシンは胃幽門洞潰瘍形成 を抑制し，潰瘍治癒を促進した。一方，カプサイシ ンの高用量（神経毒性を示す用量）を処置すると, 胃幽門洞潰瘍はかえってひどく悪化することが観察 された. ${ }^{8)}$ トウガラシはその摂取量によって，胃に 対してベル型の薬理作用を示す。したがって，トウ ガラシの胃保護作用を過信して食べすぎると，思い もよらない非常事態になりかねない.

\section{6. 下部消化管における TRPV1 発現知覚神経の} 分布と役割

口から直腸にいたる消化管のほぼ全域で，壁内神 経叢や筋層, 粘膜下層の外来性知覚神経に TRPV1 が発現していることが明らかにされている. ${ }^{9)}$ 壁内 神経叢では TRPV1 発現知覚神経が内在性神経の細 胞体を取り囲むような形態をとっており，末梢内在 性神経と外来神経との間の情報伝達に重要な役割を 担っていると考えられる.

私たちはマウス下部消化管切片における TRPV1 発現神経線維の分布についても検討を行っている. 
下部消化管においても TRPV1 免疫反応性の細胞体 は見い出せなかった。直腸では TRPV1 神経線維は 粘膜下層の血管周囲, 筋間神経叢に豊富に存在して おり，粘膜層においても存在が確認された。 上述の 胃粘膜層において，TRPV1 神経線維は胃腺に沿つ て管腔側にまっすぐ走っていたが，直腸粘膜層にお いては腸腺を横切って走行している TRPV1 神経線 維が観察された。下部消化管への侵害刺激に対する センサーとしての TRPV1 機能を考える上で，粘膜 層における TRPV1 発現神経線維の走行の違いは興 味深い。カプサイシン感受性知覚神経は，軸索-軸 索反射によって管腔や腸管壁の化学的変化や物理的 変化に応答している。 また，カプサイシン感受性知 覚神経と腸管内在性知覚神経との相互作用が，消化 活動，血流，運動性，分泌活動に影響を与えてい る. ${ }^{10,11)}$

カプサイシンや TRPV1 阻害薬を用いた解析から, TRPV1（若しくは TRPV1 発現神経）の活性化は, 粘液分泌充進, 血流増加, 大腸上皮細胞増殖促進, 運動六進など様々な作用を持つことが明らかになつ ており，腸管の知覚神経に発現している TRPV1 は，胃と同様に粘膜保護や創傷治癒に重要な役割を 果たしているものと推定される.

一方，腸の炎症に伴う痛覚過敏にも関与する. ヒ 卜においては，炎症性腸疾患（inflammatory bowel disease；IBD）や過敏性腸症候群（irritable bowel syndrome； IBS）で TRPV1の発現が変化すること が報告されている。IBD 患者の結腸において， TRPV1 発現神経線維の増大が観察されている。結 腸の知覚神経に発現する TRPV1 はアナンダミドを 含む脂質によって活性化されるとともに，種々の炎 症関連メディエーターによって TRPV1 の活性化温 度閾値が低下して体温でも活性化され得るようにな る. 炎症関連メディエーターには，セロトニン，プ ロスタグランジン，トリプシン，トリプターゼ等が 結腸で放出されることが知られており，それらの受 容体が活性化すると TRPV1の増感作が惹起され て, 炎症性痛覚過敏が起こるものと推定される. 大 腸由来の培養セロトニン受容体発現神経細胞の電気 生理学的な解析によって，セロトニンによる TRPV1 の感作が確認されている，大腸炎の疼痛発 生に TRPV1 が係わることはまちがいないが, TRPV1 の大腸炎発症における役割については一定
の結論が得られておらず，更なる検討が必要である.

\section{7. 腸におけるカプサイシンの平滑筋収縮作用}

カプサイシンの摘出腸管標本に対する収縮作用の 機序に関してはモルモットの回腸を用いた報告が多 くある. カプサイシンの回腸収縮作用は，カプサイ シンが知覚神経上の TRPV1 を介して最終神経伝達 物質としてアセチルコリンを遊離することにより引 き起こされていた. ${ }^{10)}$ さらに，この収縮反応に関与 する神経伝達物質として，タキキニン類の関与が報 告されている。 また，カプサイシンにはモルモット 回腸に対する興奮性の作用のほかに，CGRP を介 する弛緩作用を示すことも報告されている.

私たちは下部消化管に着目し, マウス摘出直腸, 遠位結腸，横行結腸，近位結腸平滑筋標本を作製 し，カプサイシンの平滑筋収縮作用についてマグヌ ス法にて検討を行った。その結果，近位結腸<横行 結腸＜直腸＜遠位結腸の順にカプサイシンに対する 感受性が高かった。したがって，肛門側の方がより カプサイシン感受性知覚神経の影響を受け易いと考 えられる，送便部結腸である遠位結腸と直腸でカプ サイシン感受性が高かったことより，大腸運動能と 知覚神経の密接な連関が窥われた。 ${ }^{12)}$

\section{8. 消化管の知覚過敏}

ヒトにおいて，自律神経の失調によって大腸が異 常収縮し，痤攣を起こしたようになる痤攣性の便秘 が起きることがある．また，便秘とは反対の下痢症 の中にも，蠕動運動の過剩六進が大きな引き金と なっているケースもある.このような消化管運動異 常による便秘や下痢では，高頻度で腹痛を伴ってお り，これには消化管知覚過敏の関与が考えられる. 近年，過敏性腸症候群の患者の直腸 $\mathrm{S}$ 状部の粘膜 生検において熱刺激受容体 TRPV1 免疫反応性が健 常者と比べて 3.5 倍に増加することが報告され，こ の TRPV1 の発現上昇が痛覚過敏に関与することが 示唆された. ${ }^{13)}$ また，機能性胃腸症の患者において もカプサイシンに対する反応の感受性が上昇するこ とが報告されている. ${ }^{14)}$ さらに, 炎症性腸疾患や胃 食道逆流症の患者の結腸組織サンプルにおいても TRPV1 免疫反応性の増大が認められている.

覚醒下マウスの実験では, 遠位結腸にカプサイシ ンを投与すると, 腹部の収縮を伴う疼痛反射が観察 された. ${ }^{15)}$ また，TRPV1ノックアウトマウスを用 いた検討では，消化管壁への加圧刺激にともなう疼 


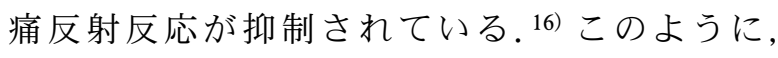
TRPV1 は内臓痛にも重要な役割を演じていること がわかってきた. デキストラン硫酸惹起大腸炎モデ ルマウスにおいて, 粘膜層の TRPV1 発現神経線維 の数及びカプサイシン惹起疼痛反応が増加すること も報告された. ${ }^{17,18)}$ このように，炎症によって引き 起こされる下部消化管の痛覚過敏性増大には TPRV1 反応性増大が関与していると考えられる。

では，この TRPV1 反応性増大がなぜ起こるので あろうか。これについてはまだ完全には解明されて いない．神経成長因子 (nerve growth factor; NGF) やその受容体であるニューロトロフィン受容体 TrkA が，腸の炎症部位において産生増大すること

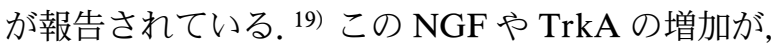
TRPV1 発現神経の数の増大を惹起しているものと 推察される.ラット酢酸潰瘍モデルにおいて，胃壁 加圧刺激に対する痛覚過敏性は抗 NGF 抗体によっ て抑制されている. ${ }^{20)}$

急性炎症性疼痛発生メカニズムの 1 つとして, 炎 症性メディエーターが TRPV1 をリン酸化して機能 増強することが報告されている，すなわち，炎症時 に産生されるブラジキニンやプロスタグランジンな ごが知覚神経に存在するそれぞれの受容体を刺激す ると, 細胞内情報伝達系が流れ，プロテインキナー ゼ C が活性化して，TRPV1 をリン酸化するという ものである。このようなメカニズムは炎症による消 化管知覚過敏にも関与していると考えられる。 この ように，熱刺激受容体 TRPV1 は，炎症局所で産生 される内因性メディエーターによって発現調節，あ るいは活性化調節を受け，消化管知覚過敏などの病 態を引き起こしているものと考えられる.

9. おわりに トウガラシの辛味は胃腸でも味わ う

トウガラシは食欲増進，健胃，脂肪燃焼，免疫力 増大などの薬理作用を有するが，この作用点は TRPV1である。 トウガラシの辛味は舌で味わうも のであるが，スパイスセンサー TRPV1 の消化管に おける分布から考えると，辛味は口から肚門までの 消化管全域で受容していると考えられる．このよう に，トウガラシのほどよい辛味は胃腸でも味わい, 胃腸に対してよい影響，場合によっては悪い影響を 与えている。 また，TRPV1 は，トウガラシ辛味成 分, 酸, 熱刺激という複数の痛夕刺激を感知する力
チオンチャネルである.TRPV1 は消化管の求心性 一次知覚神経にも多く発現することが明らかになっ ているが，消化管では疼痛発生以外に消化管粘膜保 護などの消化管の生理的機能に深く係わっている.

カプサイシンの刺激作用は用量に依存的であり, 少量の㩒取では求心性一次知覚神経を選択的に興奮 させる。，一方，大量の急性摂取ではこの知覚神経を 機能的に麻痺させる. カプサイシンの用量作用曲線 はベル型になるという特徵を有する。ささらに，カプ サイシンの大量慢性摂取は, 知覚神経を退行変性し てしまうほど強い効果を有している，すなわち，少 量から有益な作用が始まるが，適量で最大反応とな り，それを過ぎると有益な効果は減弱し，最後には 有害作用の方向へ転じるということになる，医師・ 薬剤師は，「胃が荒れた患者には刺激性のある香辛 料はとらないでください」と指導する。これは，胃 潰瘍状態では TRPV1 発現神経が増え TRPV1 が増 感作しているので, 普段の適量が過剩量になってし まうものと思われる.

医薬品開発においては，鎮痛を目標として多くの バニロイド受容体 TRPV1 拮抗薬の開発が世界中で 進んでいる。また，過敏性腸症候群，潰瘍性大腸 炎，気管支喘息，偏頭痛，過活動膀胱において共通 してみられる知覚過敏にも TRPV1 の関与が示唆さ れ，TRPV1 遮断薬の開発が模索されている。この ようにスパイスセンサーTRPV1 は新しい創薬ター ゲットとしても注目を集めている.

倫理指針 動物実験は城西国際大学動物実験倫理 委員会で承認され，動物実験などに関する規定に 従って実施された。

謝辞本研究は JSPS 科研費 JP15K07968, JP26460127, JP16K08287 の助成を受けたものであ る.

利益相反＼cjkstart開示すべき利益相反はない.

\section{REFERENCES}

1) Patapoutian A., Peier A. M., Story G. M., Viswanath V., Nat. Rev. Neurosci., 4, 529539 (2003).

2) Tominaga M., Nippon Yakurigaku Zasshi, 124, 219-227 (2004). 
3) Caterina M. J., Julius D., Annu. Rev. Neurosci., 24, 487-517 (2001).

4) Horie S., Yamamoto H., Michael G. J., Uchida M., Belai A., Watanabe K., Priestley J. V., Murayama T., Scand. J. Gastroeonterol., 39, 303-312 (2004).

5) Yeoh K. G., Kang J. Y., Yap I., Guan R., Tan C. C., Wee A., Teng C. H., Dig. Dis. Sci., 40, 580-583 (1995).

6) Holzer P., Gastroenterology, 114, 823-839 (1998).

7) Takeuchi K., Kato S., Takeeda M., Ogawa Y., Nakashima M., Matsumoto M., J. Pharmacol. Exp. Ther., 304, 1055-1062 (2003).

8) Yamamoto H., Horie S., Uchida M., Tsuchiya S., Murayama T., Watanabe K., Eur. J. Pharmacol., 432, 203-210 (2001).

9) Ward S. M., Bayguinov J., Won K. J., Grundy D., Berthoud H. R., J. Comp. Neurol., 465, 121-135 (2003).

10) Barthó L., Benkó R., Patacchini R., Pethö G., Holzer-Petsche U., Holzer P., Lázár Z., Undi S., Illényi L., Antal A., Horváth O. P., Eur. J. Pharmacol., 500, 143-157 (2004) .

11) Holzer P., Auton. Neurosci., 125, 70-75 (2006).
12) Matsumoto K., Kurosawa E., Terui H., Hosoya T., Tashima K., Murayama T., Priestley J. V., Horie S., Am. J. Physiol. Gastrointest. Liver Physiol., 297, G348-G360 (2009).

13) Akbar A., Yiangou Y., Facer P., Walters J. R., Anand P., Ghosh S., Gut, 57, 923-929 (2008).

14) Hammer J., Führer M., Pipal L., Matiasek J., Neurogastroenterol. Motil., 20, 125-133 (2008) .

15) Laird J. M., Martinez-Caro L., Garcia-Nicas E., Cervero F., Pain, 92, 335-342 (2001).

16) Jones R. C., Xu L., Gebhart G. F., J. Neurosci., 25, 10981-10989 (2005).

17) Eijkelkamp N., Kavelaars A., Elsenbruch S., Schedlowski M., Holtmann G., Heijnen C. J., Am. J. Physiol., 293, G749-G757 (2007) .

18) Matsumoto K., Lo M. W., Hosoya T., Tashima K., Takayama H., Murayama T., Horie S., Lab. Invest., 92, 769-782 (2012) .

19) Chan C. L., Facer P., Davis J. B., Smith G. D., Egerton J., Bountra C., Williams N. S., Anand P., Lancet, 361, 385-391 (2003).

20) Lamb K., Kang Y. M., Gebhart G. F., Bielefeldt K., Neurogastroenterol. Motil., 15, 355-361 (2003). 